\title{
Front Matter: Volume 10384
}

, "Front Matter: Volume 10384," Proc. SPIE 10384, Optical Data Storage 2017: From New Materials to New Systems, 1038401 (25 October 2017); doi: $10.1117 / 12.2295747$

SPIE Event: SPIE Optical Engineering + Applications, 2017, San Diego, California, SPIE. United States 


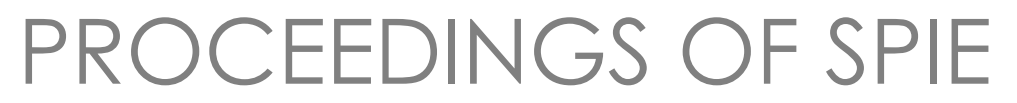

\title{
Optical Data Storage 2017: From New Materials to New Systems
}

\author{
Ryuichi Katayama \\ Yuzuru Takashima \\ Editors
}

\author{
6 August 2017 \\ San Diego, California, United States \\ Sponsored and Published by \\ SPIE
}


The papers in this volume were part of the technical conference cited on the cover and title page. Papers were selected and subject to review by the editors and conference program committee. Some conference presentations may not be available for publication. Additional papers and presentation recordings may be available online in the SPIE Digital Library at SPIEDigitalLibrary.org.

The papers reflect the work and thoughts of the authors and are published herein as submitted. The publisher is not responsible for the validity of the information or for any outcomes resulting from reliance thereon.

Please use the following format to cite material from these proceedings:

Author(s), "Title of Paper," in Optical Data Storage 2017: From New Materials to New Systems, edited by Ryuichi Katayama, Yuzuru Takashima, Proceedings of SPIE Vol. 10384 (SPIE, Bellingham, WA, 2017) Seven-digit Article CID Number.

ISSN: 0277-786X

ISSN: 1996-756X (electronic)

ISBN: 9781510612259

ISBN: 9781510612266 (electronic)

Published by

SPIE

P.O. Box 10, Bellingham, Washington 98227-0010 USA

Telephone +1 3606763290 (Pacific Time) · Fax +1 3606471445

SPIE.org

Copyright (C) 2017, Society of Photo-Optical Instrumentation Engineers.

Copying of material in this book for internal or personal use, or for the internal or personal use of specific clients, beyond the fair use provisions granted by the U.S. Copyright Law is authorized by SPIE subject to payment of copying fees. The Transactional Reporting Service base fee for this volume is $\$ 18.00$ per article (or portion thereof), which should be paid directly to the Copyright Clearance Center (CCC), 222 Rosewood Drive, Danvers, MA 01923. Payment may also be made electronically through CCC Online at copyright.com. Other copying for republication, resale, advertising or promotion, or any form of systematic or multiple reproduction of any material in this book is prohibited except with permission in writing from the publisher. The CCC fee code is 0277$786 \mathrm{X} / 17 / \$ 18.00$.

Printed in the United States of America.

Publication of record for individual papers is online in the SPIE Digital Library.

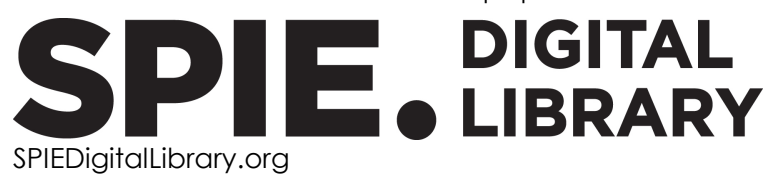

Paper Numbering: Proceedings of SPIE follow an e-First publication model. A unique citation identifier (CID) number is assigned to each article at the time of publication. Utilization of CIDs allows articles to be fully citable as soon as they are published online, and connects the same identifier to all online and print versions of the publication. SPIE uses a seven-digit CID article numbering system structured as follows:

- The first five digits correspond to the SPIE volume number.

- The last two digits indicate publication order within the volume using a Base 36 numbering system employing both numerals and letters. These two-number sets start with 00, 01, 02, 03, 04, 05, 06, 07, 08, 09, OA, OB ... 0Z, followed by 10-1Z, 20-2Z, etc. The CID Number appears on each page of the manuscript. 


\title{
Contents
}

\author{
$\checkmark \quad$ Authors \\ vii Conference Committee \\ ix Introduction
}

SESSION 1 SYSTEMS AND APPLICATIONS

1038402 Optical technologies for the Internet of Things era (Invited Paper) [10384-1]

1038404 Possibility of the market expansion of large capacity optical cold archive (Invited Paper) [10384-3]

\section{SESSION 2 HOLOGRAPHIC DATA STORAGE}

1038406 Cavity enhanced eigenmode multiplexing for volume holographic data storage [10384-5]

1038407 Eigenmode multiplexing with SLM for volume holographic data storage [10384-6]

$10384 \mathrm{OA}$ Effect of temperature change in microholographic recording [10384-9]

SESSION 3 NANOPHOTONICS

10384 OF SIL-STED microscopy technique enhancing super-resolution of fluorescence microscopy (Invited Paper) [10384-14]

SESSION 4 EMERGING AND ELEMENTAL TECHNOLOGIES

10384 OH Mastering multi-depth bio-chip patterns with DVD LBRs (Invited Paper) [10384-16]

10384 Ol An application of OFDM method to optical disc recording [10384-17] 
Proc. of SPIE Vol. 10384 1038401-4

Downloaded From: https://www.spiedigitallibrary.org/conference-proceedings-of-spie on 26 Apr 2023 Terms of Use: https://www.spiedigitallibrary.org/terms-of-use 


\title{
Authors
}

Numbers in the index correspond to the last two digits of the seven-digit citation identifier (CID) article numbering system used in Proceedings of SPIE. The first five digits reflect the volume number. Base 36 numbering is employed for the last two digits and indicates the order of articles within the volume. Numbers start with 00, 01, 02, 03, 04, 05, 06, 07, 08, 09, 0A, 0B...0Z, followed by 10-1Z, 20-2Z, etc.

\author{
Carson, Doug, $\mathrm{OH}$ \\ Chen, Guanghao, 07 \\ Choi, Guk-Jong, OF \\ Ji, Philip N., 02 \\ Katayama, Ryuichi, OA \\ Lee, Won-sup, OF \\ Lim, Geon, OF \\ Matsumoto, Ikuo, 04 \\ Miller, Bo E., 06, 07 \\ Moon, Hyungbae, OF \\ Park, No-Cheol, OF \\ Park, Young-Pil, OF \\ Saito, Kimihiro, 0 I \\ Sakata, Emiko, 04 \\ Takashima, Yuzuru, 06, 07
}


Proc. of SPIE Vol. 10384 1038401-6

Downloaded From: https://www.spiedigitallibrary.org/conference-proceedings-of-spie on 26 Apr 2023 Terms of Use: https://www.spiedigitallibrary.org/terms-of-use 


\title{
Conference Committee
}

\author{
Conference Chairs
}

Ryuichi Katayama, Fukuoka Institute of Technology (Japan)

Yuzuru Takashima, College of Optical Sciences, The University of Arizona (United States)

Program Track Chairs

Shizhuo Yin, The Pennsylvania State University (United States)

Ruyan Guo, The University of Texas at San Antonio (United States)

Conference Program Committee

Min Gu, RMIT University (Australia)

Thomas D. Milster, College of Optical Sciences, The University of Arizona (United States)

Kimihiro Saito, Kindai University Technical College (Japan)

Luping Shi, Tsinghua University (China)

Kenichi Shimada, Hitachi, Ltd. (Japan)

Xiaodi Tan, Beijing Institute of Technology (China)

Din Ping Tsai, Research Center for Applied Sciences - Academia Sinica (Taiwan)

Session Chairs

1 Systems and Applications

Yuzuru Takashima, The University of Arizona (United States)

2 Holographic Data Storage

Ryuichi Katayama, Fukuoka Institute of Technology (Japan)

Yuzuru Takashima, The University of Arizona (United States)

3 Nanophotonics

Kimihiro Saito, Kindai University Technical College (Japan)

4 Emerging and Elemental Technologies

Ryuichi Katayama, Fukuoka Institute of Technology (Japan) 
Proc. of SPIE Vol. 10384 1038401-8

Downloaded From: https://www.spiedigitallibrary.org/conference-proceedings-of-spie on 26 Apr 2023 Terms of Use: https://www.spiedigitallibrary.org/terms-of-use 


\section{Introduction}

This proceedings volume is a collection of papers based on the invited and contributed presentations at the Optical Data Storage (ODS) 2017 conference, which was held on 6 August 2017 at the San Diego Convention Center as part of the SPIE Optics + Photonics 2017.

The ODS had been held as a stand-alone conference from 1973 to 2012 and has been held as part of larger conferences since 2013. This was the fourth time for the ODS to be held in the SPIE Optics + Photonics. This time, we added the subtitle "From New Materials to New Systems" to the conference name to highlight that the optical data storage field covers a broad range of topics.

During the ODS 2017 active discussions on latest topics were observed. A total of 18 papers (10 invited papers and 8 contributed papers) were presented orally. There were high-quality presentations about systems and applications, especially on holographic data storage, nanophotonics, and emerging and elemental technologies. One thing we have to regret is that the average number of attendees for each session in this year became smaller than those in the past three years. Nonetheless, presentation and discussions during the ODS 2017 shows that there will be a demand for 10 TB-order optical data storage in the future professional archival storage market, and the effort of the related researchers to meet this demand will be strongly expected.

We are very happy that a total of 8 papers are contained in this proceedings volume. They represent important and interesting achievements in the current field of optical data storage. We hope that the readers find this proceedings volume stimulating and exciting, as well as helpful for their future research and development.

We would like to have the ODS 2018 as part of the SPIE Optics + Photonics 2018, which will be officially announced later. To activate the ODS more, we are planning to add a new topic that is related to optics for industrial applications but not restricted to optical data storage, and to organize a special session on this topic.

Finally, we would like to express our sincere gratitude to the committee members, session chairs, and all of the presenters and attendees of the ODS 2017 as well as the SPIE staff for their great contributions.

Ryuichi Katayama Yuzuru Takashima 
Proc. of SPIE Vol. 10384 1038401-10 Downloaded From: https://www.spiedigitallibrary.org/conference-proceedings-of-spie on 26 Apr 2023
Terms of Use: https://www.spiedigitallibrary.org/terms-of-use 